\title{
Faktor Penyebab Putus Berobat terhadap Pasien Gangguan Jiwa Rawat Jalan di Rumah Sakit Jiwa
}

\author{
Riskanta Manik*, Arifah Devi Fitriani, Jamaluddin \\ Program Studi Kesehatan Masyarakat, Institut Kesehatan Helvetia. \\ *email: riskanta80@gmail.com
}

\begin{abstract}
ABSTRAK
Putus obat pada pasien gangguan jiwa adalah berhentinya suatu proses pengobatan sebelum menyelesaikan pengobatan yang disarankan. Rumah Sakit Jiwa Kawala Atei Provinsi Kalimantan Tengah memiliki angka kunjungan dengan kejadian pasien putus berobat di atas $50 \%$, pada tahun 2019 sampai bulan Juni diketahui bahwa angka pasien putus berobat ada sebanyak 172 pasien dari 256 pasien yang berkunjung. Tujuan penelitian ini yaitu untuk menganalisis faktor penyebab putus berobat terhadap pasien gangguan jiwa rawat jalan di Rumah Sakit Jiwa Kalawa Atei Kalimantan Tengah tahun 2019. Jenis penelitian adalah survei analitik dengan rancangan cross sectional study, Penelitian ini dilakukan di Rumah Sakit Jiwa Kalawa Atei Kalimantan Tengah pada bulan November sampai dengan Desember 2019. Populasi dalam penelitian ini adalah seluruh keluarga yang memiliki anggota keluarga yang mengalami gangguan jiwa putus berobat sebanyak 256 orang. Sampel penelitian sebanyak 78 orang dengan menggunakan purposive sampling. Data dianalisis dengan rumus chi-square dan regresi logistik. Berdasarkan hasil penelitian, diketahui bahwa adapun faktor yang memengaruhi kejadian putus berobat terhadap pasien gangguan jiwa rawat jalan di Rumah Sakit Jiwa Kalawa Atei Kalimantan Tengah tahun 2019 adalah kemampuan ekonomi $(p=0,024)$, jarak $(p=0,000)$, persepsi $(p=0,012)$, kepercayaan $(p=0,001)$. Berdasarkan hasil penelitian disarankan agar penelitian ini dapat dijadikan sebagai salah satu sumber informasi terkait dengan faktor yang mempengaruhi kejadian putus berobat terhadap pasien gangguan jiwa di Rumah Sakit Jiwa.
\end{abstract}

\section{Kata Kunci $\quad$ : Kemampuan Ekonomi, Jarak, Persepsi, Kepercayaan, Putus Berobat}

\section{ABSTRACT}

Drug withdrawal in a psychiatric patient is the cessation of a treatment process before completing the recommended treatment. Kawala Atei Mental Hospital of Central Kalimantan Province has a visit rate with the incidence of patients dropping out of treatment above 50\%, from 2019 to June it is known that the number of patients dropping out of treatment there are 172 patients out of 256 patients who visited. The purpose of this study was to analyze the factors causing dropouts for outpatient psychiatric patients at Kalawa Atei Mental Hospital in Central Kalimantan in 2019.This type of research is an analytic survey with a cross sectional study design. This study was conducted at the Kalei Atei Mental Hospital in Central Kalimantan in November to December 2019. The population in this study was all families who have family members who experience mental illnesses dropping out of treatment as many as 256 people. The research sample of 78 people using purposive sampling. Data were analyzed using the chi-square formula and logistic regression. Based on the results of the study, it is known that the factors that influence the incidence of outpatient treatment for outpatient psychiatric patients at the Kalei Atei Mental Hospital in Central Kalimantan in 2019 are economic ability $(p=0.024)$, distance $(p=0,000)$, perception $(p=0.012)$, trust $(p=0.001)$. Based on the results of the study it is suggested that this study can be used as a source of information related to factors that influence the incidence of treatment dropouts for psychiatric patients at the Mental Hospital.

\section{Keywords: Economic Ability, Distance, Perception, Trust, Disconnect from Treatment}

\section{PENDAHULUAN}

Rumah Sakit merupakan salah satu jaringan pelayanan kesehatan yang penting, sarat dengan tugas, beban, masalah dan harapan yang digantungkan kepadanya. Perkembangan jumlah rumah sakit di Indonesia, yang diikuti pula dengan perkembangan pola penyakit, perkembangan teknologi kedokteran dan kesehatan serta perkembangan harapan masyarakat terhadap pelayanan rumah sakit membuat rumah sakit sangat dibutuhkan sebagai suatu sistem yang baik yang dapat mengatur dan mengelola 
segala sumber rumah sakit dengan sebaikbaiknya.

Berdasarkan data World Health Organization (WHO) tahun 2018 diketahui bahwa, satu dari empat orang di dunia terjangkit gangguan jiwa atau neurologis. Saat ini, ada sekitar 450 juta orang mengalami gangguan mental dan hampir satu juta orang diantaranya melakukan bunuh diri setiap harinya. ${ }^{1}$

Di Indonesia, data Riskesdas 2017 dikombinasi dengan data rutin dari Pusat data dan Informasi menunjukkan bahwa terdapat 85.788 orang dengan gangguan jiwa berat. Dari jumlah itu, sebanyak 37.013 penderita gangguan mental berat mendapat pengobatan. Sementara 13.204 lainnya justru diasingkan, dan selebihnya tidak mendapatkan pengobatan. Jumlah tersebut masih tergolong kecil lantaran berbagai faktor. Mulai dari stigma 'gila' dan tak bisa diobati, kekurangan tenaga medis, hingga keterbatasan obat yang tersedia. ${ }^{2}$

Berdasarkan data Kementerian Kesehatan RI Tahun 2016, gejala depresi dan kecemasan sudah diidap orang Indonesia sejak usia 15 tahun. Persentase depresi mencapai 6 persen atau sekitar 14 juta orang. Sedangkan prevalensi gangguan jiwa berat, seperti skizofrenia sebanyak 1,7 per 1.000 penduduk atau sekitar 400.000 orang.

Kondisi ini diperkirakan ada kaitannya dengan banyaknya kekerasan yang dialami oleh penderita gangguan jiwa. Komisi Perlindungan Anak Indonesia (KPAl) menyebutkan, tiap tahun angka kekerasan terus meningkat. Pada tahun 2017 terjadi 3.700 kasus, dan hampir 70 persen pelakunya adalah orang tua sendiri. Anak-anak rentan gangguan kejiwaan akibat pengalaman traumatis yang diterima dari orang tua sendiri, maupun di sekolah dan lingkungan masyarakat akibat perundungan atau bullying. Gangguan jiwa juga dipicu oleh faktor sosial, seperti kemiskinan, lingkungan, dan bencana alam. Artinya akan semakin banyak orang depresi dan terganggu kesehatan jiwanya. ${ }^{3}$

Upaya penanganan terhadap orang dengan gangguan kejiwaan masih jauh dari harapan. Dengan jumlah penduduk sekitar 250 juta jiwa, Indonesia baru memilki 451 psikolog klinis ( 0,15 per 100.000 penduduk), 773 orang psikiater 0,33 per 100.000 penduduk, dan perawat jiwa 6.500 orang atau 2 persen per 100.000 penduduk. Sementara, standar WHO untuk tenaga psikolog dan psikiater dengan jumlah penduduk adalah 1 per 30 orang. ${ }^{4}$
Di Indonesia banyak keterbatasan, misalnya terapis atau ahli yang berkecimpung di dunia kesehatan jiwa sangat kurang. Rumah sakit yang menangani kesehatan jiwa juga terbatas. Bahkan, beberapa provinsi sama sekali belum melayani gangguan jiwa. Di sisi lain, masih banyak pasien yang dipasung. Meski pemerintah telah melarang pemasungan sejak 1977, berdasarkan laporan Human Right Watch Indonesia, masih ada 18.000 orang dipasung karena penyakitnya dianggap sebagai kutukan atau kerasukan setan. Di Indonesia, sebanyak 15,8 persen keluarga yang memiliki anggota keluarga yang menderita gangguan jiwa berat tidak membawa anggota keluarganya tersebut ke Rumah Sakit Jiwa untuk dilakukan pengobatan. Namun, angka itu tak mencakup keseluruhan keluarga di Indonesia. Hingga 7 Juli 2018, baru tercatat sebanyak 13 juta keluarga yang dipantau dan terdata dalam aplikasi. Angka itu hanya mencakup 20,24 persen dari seluruh keluarga di Indonesia. Padahal keluarga merupakan faktor yang sangat penting dalam proses kesembuhan penderita gangguan jiwa. ${ }^{5}$

Jumlah kunjungan di Rumah Sakit Jiwa sangat dipengaruhi oleh pelayanan petugas kesehatan di Rumah sakit Jiwa tersebut. Misalnya, apakah petugas kesehatan di rumah sakit jiwa mampu menenangkan pasien yang pertama kali dibawa berobat, sehingga keluarga pasien benar-benar yakin bahwa anggota keluarganya dapat ditangani dengan baik di Rumah Sakit tersebut, karena biasanya pasien yang pertama kali dibawa ke Rumah Sakit Jiwa untuk berobat pasti akan merontaronta, mengamuk bahkan cenderung bersikap kasar karena dia menolak untuk diobati. Tetapi pihak rumah sakit harus bisa menenangkan pasien tersebut untuk pengobatan selanjutnya. Kemudian apakah setelah diberi pengobatan dan terapi-terapi psikologis, pasien akan mulai terbiasa dan bisa beradaptasi dengan lingkungan sekitar serta mulai bisa menerima obat-obatan anti psikotik yang dia konsumsi. Selanjutnya apakah perawatan di rumah sakit jiwa dapat menurunkan stres pada pasien dan membantu mereka menyusun aktivitas harian mereka. Dengan demikian, keluarga pasien dapat diyakinkan bahwa anggota keluarganya akan aman berada dalam lingkungan Rumah Sakit Jiwa, atau bahkan berobat di Rumah Sakit Jiwa tersebut. ${ }^{6}$

Rumah Sakit Jiwa Kawala Atei Provinsi Kalimantan Tengah memiliki angka kunjungan dengan kejadian pasien putus berobat di atas $50 \%$, pada tahun 2019 sampai bulan Juni 
diketahui bahwa angka pasien putus berobat ada sebanyak 172 pasien dari 256 pasien yang berkunjung. Sejarah berdirinya Rumah Sakit Jiwa Kalawa Atei diawali pada tahun 2000 didirikan "Pusat Konsultasi Kesehatan Jiwa Masyarakat”. Pada tahun 2001 Pusat Konsultasi dan Pelayanan Kesehatan Jiwa berubah menjadi Balai Kesehatan Jiwa Masyarakat Kalawa Atei. Pada tahun 2008 Organisasi Balai Kesehatan Jiwa Masyarakat berubah nama menjadi Balai Kesehatan Kalawa Atei. Balai Kesehatan Kalawa Atei sebagai Unit Pelaksana Teknis Dinas Kesehatan Provinsi Kalimantan Tengah berperan di dalam pelayanan kesehatan jiwa masyarakat.

Berdasarkan data kunjungan di Rumah Sakit Jiwa Kalawa Atei dari tahun 2015 sampai Juni 2019 diketahui bahwa masih banyak pasien yang putus berobat, seperti pada tahun 2015, pasien yang patuh berobat hanya 86 orang pasien, sedangkan yang putus berobat ada sebanyak 181 orang pasien, tahun 2016 pasien yang patuh berobat hanya 103 orang pasien, sedangkan yang putus berobat ada sebanyak 167 orang pasien, tahun 2017 pasien yang patuh berobat hanya 91 orang pasien, sedangkan yang putus berobat ada sebanyak 168 orang pasien, tahun 2018, pasien yang patuh berobat ada sebanyak 269 orang pasien, sedangkan yang putus berobat ada sebanyak 180 orang pasien dan pada tahun 2019 pasien yang patuh berobat 84 orang pasien, sedangkan yang putus berobat ada sebanyak 172 orang pasien.

Berdasarkan hasil wawancara dengan 20 orang keluarga pasien yang putus berobat, diketahui bahwa adapun faktor yang

Tabel 1. Distribusi Karakteristik Responden di Rumah Sakit Jiwa Kalawa Atei Kalimantan Tengah

\begin{tabular}{lrr}
\hline Kelompok Umur (Tahun) & $\mathbf{n}$ & \% \\
\hline 21-25 Tahun & 10 & 12,82 \\
26-35 Tahun & 18 & 23,08 \\
36-45 Tahun & 15 & 19,23 \\
46-55 Tahun & 17 & 21,79 \\
56-65 Tahun & 18 & 23,08 \\
\hline Jenis Kelamin & & \\
Laki-laki & 29 & 37,18 \\
Perempuan & 49 & 62,82 \\
\hline Tingkat Pendidikan & & 19,23 \\
\hline SD & 15 & 34,62 \\
SMP & 27 & 37,18 \\
SMA & 29 & 8,97 \\
PT & 7 & 39,74 \\
\hline Jenis Pekerjaan & & 24,36 \\
\hline Petani & 31 & \\
Wiraswasta & 19 &
\end{tabular}


Berdasarkan tabel 1 di atas diketahui bahwa dari 78 responden, sebagian besar responden berumur 26-35 dan 56-65 tahun yaitu sebanyak $18(23,08 \%)$ responden, sedangkan responden lainnya berumur 21-25 tahun yaitu sebanyak $10(12,82 \%)$ responden, umur 36-45 tahun sebanyak $15(19,23 \%)$, umur $46-55$ tahun sebanyak 17 (21,79\%). Dari 78 responden diketahui bahwa sebagian besar responden berjenis kelamin perempuan yaitu sebanyak 49 $(62,82 \%)$ responden sedangkan responden yang berjenis kelamin laki-laki sebanyak 29 $(37,18 \%)$ responden. Dari 78 responden diketahui bahwa sebagian besar responden merupakan tamatan SMA yaitu sebanyak 29 $(37,18 \%)$ responden, tamatan SD sebanyak 15 $(19,23 \%)$ tamatan SMP sebanyak 27 (34,62\%) responden dan tamatan PT ada sebanyak 7 $(8,97 \%)$ responden.

Untuk mengetahui perilaku masyarakat dalam pemberantasan malaria

Tabel 3. Faktor - Faktor yang Memengaruhi Kejadian Putus Berobat Terhadap Pasien Gangguan Jiwa Rawat Jalan di Rumah Sakit Jiwa Kalawa Atei Kalimantan Tengah

\begin{tabular}{|c|c|c|c|c|c|c|c|}
\hline \multirow{3}{*}{ Kemampuan Ekonom } & \multicolumn{6}{|c|}{ Putus Berobat } & \multirow{3}{*}{$\begin{array}{c}p \\
\text { value }\end{array}$} \\
\hline & \multicolumn{2}{|c|}{ Putus Berobat } & \multicolumn{2}{|c|}{$\begin{array}{c}\text { Tidak putus } \\
\text { Berobat }\end{array}$} & \multicolumn{2}{|c|}{ Total } & \\
\hline & $\mathbf{n}$ & $\%$ & $\mathbf{n}$ & $\%$ & $\mathbf{n}$ & $\%$ & \\
\hline Tidak Mampu & 41 & 75,9 & 13 & 17,3 & 54 & 100 & \\
\hline Mampu & 12 & 50,0 & 12 & 50,0 & 24 & 100 & 0,024 \\
\hline Jumlah & 53 & 67,9 & 25 & 32,1 & 78 & 100 & \\
\hline \multirow{3}{*}{ Jarak } & \multicolumn{6}{|c|}{ Putus Berobat } & \multirow[b]{2}{*}{$\mathrm{p}$ value } \\
\hline & \multicolumn{2}{|c|}{$\begin{array}{c}\text { Putus } \\
\text { Berobat }\end{array}$} & \multicolumn{2}{|c|}{$\begin{array}{c}\text { Tidak putus } \\
\text { Berobat }\end{array}$} & \multicolumn{2}{|c|}{ Total } & \\
\hline & $\mathbf{n}$ & $\%$ & $\mathbf{n}$ & $\%$ & $\mathbf{n}$ & $\%$ & \\
\hline Tidak Terjangkau & 43 & 84,3 & 8 & 15,7 & 51 & 100 & \\
\hline Terjangkau & 10 & 37,0 & 17 & 63,0 & 27 & 100 & 0,000 \\
\hline Jumlah & 53 & 67,9 & 25 & 32,1 & 78 & 100 & \\
\hline \multirow{3}{*}{ Persepsi } & \multicolumn{6}{|c|}{ Putus Berobat } & \multirow{3}{*}{$\begin{array}{c}p \\
\text { value }\end{array}$} \\
\hline & \multicolumn{2}{|c|}{ Putus Berobat } & \multicolumn{2}{|c|}{$\begin{array}{c}\text { Tidak putus } \\
\text { Berobat }\end{array}$} & \multicolumn{2}{|c|}{ Total } & \\
\hline & $\mathbf{n}$ & $\%$ & $\mathbf{n}$ & $\%$ & $\mathbf{n}$ & $\%$ & \\
\hline Negatif & 37 & 78,7 & 10 & 21,3 & 47 & 100 & \\
\hline Positif & 16 & 51,6 & 15 & 48,4 & 31 & 100 & 0,012 \\
\hline Jumlah & 53 & 67,9 & 25 & 32,1 & 78 & 100 & \\
\hline \multirow{3}{*}{ kepercayaan } & \multicolumn{6}{|c|}{ Putus Berobat } & \multirow[b]{2}{*}{$\begin{array}{c}p \\
\text { value }\end{array}$} \\
\hline & \multicolumn{2}{|c|}{ Putus Berobat } & \multicolumn{2}{|c|}{$\begin{array}{c}\text { Tidak putus } \\
\text { Berobat }\end{array}$} & \multicolumn{2}{|c|}{ Total } & \\
\hline & $\mathbf{n}$ & $\%$ & $\mathbf{n}$ & $\%$ & $\mathbf{n}$ & $\%$ & \\
\hline Negatif & 44 & 78,6 & 12 & 21,4 & 56 & 100 & \\
\hline Positif & 9 & 40,9 & 13 & 59,1 & 22 & 100 & 0,001 \\
\hline Jumlah & 53 & 67,9 & 25 & 32,1 & 78 & 100 & \\
\hline
\end{tabular}

Berdasarkan tabel 1 diketahui bahwa dari 78 responden yang diteliti, sebagian besar responden tidak mampu secara kemampuan ekonomi sebanyak $54(69,2 \%)$ responden. Dari $54(69,23 \%)$ responden tersebut, ada sebanyak 41 (75,9\%) responden tidak mampu secaara ekonomi dan putus berobat, sebanyak $13(17,3 \%)$ responden tidak mampu secaara ekonomi dan tidak putus berobat. Berdasarkan hasil perhitungan uji statistik diperoleh nilai $p$ significancy yaitu $0,024<0,05$, sehingga dapat disimpulkan bahwa ada pengaruh kemampuan ekonomi terhadap kejadian putus berobat terhadap pasien gangguan jiwa rawat jalan di Rumah Sakit Jiwa Kalawa Atei Kalimantan Tengah tahun 2019, dari 78 responden yang diteliti, sebagian besar responden mengatakan jarak tidak terjangkau 
sebanyak $43(55,1 \%)$ responden. Dari 43 $(55,1 \%)$ responden tersebut, ada sebanyak 43 $(84,3 \%)$ responden mengatakan jarak tidak terjangkau dan putus berobat, sebanyak 8 $(15,7 \%)$ responden mengatakan jarak tidak terjangkau dan tidak putus berobat. Berdasarkan hasil perhitungan uji statistik diperoleh nilai $p$ significancy yaitu $0,000<$ 0,05 , sehingga dapat disimpulkan bahwa ada pengaruh jarak terhadap kejadian putus berobat terhadap pasien gangguan jiwa rawat jalan di Rumah Sakit Jiwa Kalawa Atei Kalimantan Tengah tahun 2019, dari 78 responden yang diteliti, sebagian besar responden memiliki persepsi negatif sebanyak $47(60,2 \%)$ responden. Dari $47 \quad(60,2 \%)$ responden tersebut, ada sebanyak $37(78,7 \%)$ responden memiliki persepsi negatif dan putus berobat, sebanyak $10(21,3 \%)$ responden memiliki persepsi negatif dan tidak putus berobat. Berdasarkan hasil perhitungan uji statistik diperoleh nilai $\mathrm{p}$ significancy yaitu $0,012<0,05$, sehingga dapat disimpulkan bahwa ada pengaruh persepsi terhadap kejadian putus berobat terhadap pasien gangguan jiwa rawat jalan di Rumah Sakit Jiwa Kalawa Atei Kalimantan Tengah tahun 2019, dari 78 responden yang diteliti, sebagian besar responden meiliki keppercayaan negatif sebanyak $56(71,7 \%)$ responden. Dari 56 $(71,7 \%)$ responden tersebut, ada sebanyak 44 $(78,6 \%)$ responden meiliki keppercayaan negatif dan putus berobat, sebanyak 12 $(21,4 \%)$ responden meiliki keppercayaan negatif dan tidak putus berobat. Berdasarkan hasil perhitungan uji statistik diperoleh nilai $p$ significancy yaitu $0,001<0,05$, sehingga dapat disimpulkan bahwa ada pengaruh kepercayaan terhadap kejadian putus berobat terhadap pasien gangguan jiwa rawat jalan di Rumah Sakit Jiwa Kalawa Atei Kalimantan Tengah tahun 2019.

\section{PEMBAHASAN}

Status ekonomi keluarga merupakan suatu komponen kelas sosial yang menunjukkan tingkat, dan sumber penghasilan keluarga serta gambaran keadaan keluarga dimana keluarga merupakan komponen dasar yang dapat menentukan derajat kelas ekonomi, yang terdiri dari kelas atas, menengah, dan kelas bawah. ${ }^{7}$ Sosial ekonomi yang rendah menjadi salah satu dari faktor prognosis buruk yang dapat memicu terjadinya kejadian putus berobat terhadap pasien gangguan jiwa
Kejadian putus berobat terhadap pasien gangguan jiwa memiliki dampak bagi keluarga pasien dan rumah sakit. Keluarga pasien merasakan beban moral dikarenakan anggapan negatif dari masyarakat mengenai pasien gangguan selain itu keluarga mengalami kesusahan dari segi materi karena seringnya pasien mengalami kambuh dan menyebabkan jumlah pengeluaran meningkat utuk berobat; bagi pasien itu sendiri dipandang buruk dalam lingkungannya serta penerimaan yang sulit dari masyarakat; bagi pihak rumah sakit bertambahnya jumla pasien akibat kambuh menyebabkan peningkatan jumlah pasien yang di rawat sehingga mempengaruhi kualitas dari perawatan pasien.

Pada penelitian ini status ekonomi keluarga dapat menjadi faktor yang sangat penting dikarenakan kebanyakan dari responden penelitian yang ditemukan dalam penelitian ini mengatakan memiliki banyak kesulitan terutama masalah yang terkait dengan ekonomi salah satunya yaitu biaya pengobatan, penghasilan yang tidak mendukung dari ekonomi pasien, tidak memiliki jaminan kesehatan untuk berobat dengan alasan tidak ada uang untuk membuat jaminan kesehatan, selain itu responden mengatakan bahwa pekerjaanya hanyalah wiraswasta sehingga hanya sedikit uang yang didapatkan dalam sebulan, tidak cukup digunakan untuk penggobat, ada juga responden yang tidak menyadari bahwa masalah kekambuhan merupakan sesuatu yang serius dikarenakan pengetahuan responden mengenai kekambuhan masih belum cukup. Menurut Sariah., Outwaater., \& Malima, (2014) menyatakan bahwa keluarga pasien dengan status ekonomi rendah seringkali mengalami kesulitan dalam pengobatan pasien dikarenakan tidak mampu untuk membeli obat, hal ini mengakibatkan pasien putus berobat terhadap pasien gangguan jiwa. $^{8}$

Penelitian ini ditemukan banyak keluarga pasien dengan status ekonomi rendah sehingga berdampak yang serius bagi keluarga pasien dan juga pasien diantaranya berdampak pada kerutinan pasien untuk kontrol, sering kali habis obat namun enggan untuk membeli obat karena tidak ada uang, penenuhan kebutuhan hidup tidak terpenuhi, menyebabkan kesulitan bagi keluarga dari segi materi dan lainya. Status ekonomi rendah sangat mempenggaruhi kehidupan seseorang. Himpitan ekonomi memicu orang menjadi rentan terhadap gangguan mental. Kemiskinan menimbulkan berbagai masalah yang 
menyulitkan kehidupan. Kemiskinan meningkatkan rasa frustasi seseorang sehingga pasien putus berobat terhadap pasien gangguan jiwa pada keluarga miskin cenderung sering mengalami kekambuhan. ${ }^{9}$

Jarak tempat tinggal dengan rumah sakit juga menjadi penyebab ketidakpatuhan dalam kontrol berobat. Jarak tempat tinggal merupakan jauh dekatnya perjalanan yang harus ditempuh oleh pasien dalam pengobatan. Semakin jauh jarak tempat tinggal dari fasilitas kesehatan, semakin besar risiko terjadinya ketidak patuhan kontrol berobat.

Rawat jalan adalah salah satu unit kerja dirumah sakit atau suatu pelayanan kesehatan yang melayani pasien berobat jalan dan tidak lebih dari 24 jam pelayanan, termasuk seluruh prosedur diagnostik dan terapeutik. Pelayanan rawat jalan merupakan pelayanan kepada pasien untuk observasi, diagnosa pengobatan, rehabilitasi medik dan pelayanan kesehatan lainnya yang bersifat umum, spesialistik, sub spesialistik yang dilaksanakan di suatu rumah sakit atau layanan kesehatan tanpa tinggal rawat inap (Agustiawan \& Andri ) Salah satu program dalam rawat jalan adalah rehabilitasi kejiwaan yang mengacu pada layanan yang dirancang untuk mempromosikan proses pemulihan untuk orang dengan penyakit mental. Program rawat jalan bertujuan untuk mengontrol gejala dan memanajemen pengobatan untuk pemberdayaan dan peningkatan kualitas hidup. Pelayanan rawat jalan lebih mengedepankan komunitas yang berbasis masyarakat. ${ }^{10}$

Jarak tempat tinggal dengan rumah sakit juga menjadi penyebab ketidakpatuhan dalam berobat. Jarak tempat tinggal merupakan jauh dekatnya perjalanan yang harus ditempuh oleh pasien dalam pengobatan. Semakin jauh jarak tempat tinggal dari fasilitas kesehatan, semakin besar risiko terjadinya ketidak patuhan berobat.

Penyebab terjadinya putus berobat dan ketidak patuhan berobat antara lain kesulitan finansial dan jauhnya jarak dari rumah sakit. Peran keluarga tidak dapat dipisahkan dalam perawatan pada pasien skizofrenia. Hal tersebut mengingat bahwa pasien skizofrenia mengalami penurunan fungsi kognitif, beberapa peneliti menunjukkan bahwa salah satu faktor penyebab kambuhnya pasien dengan gangguan jiwa adalah perilaku keluarga yang tidak tahu cara menangani pasien skizofreniadi rumah. ${ }^{11}$

Hal ini tidak sesuai dengan pernyataan
Niven (2002) menyatakan bahwa salah satu faktor yang mempengaruhi kepatuhan berobat adalah faktor yang mendukung (enabling factor), yang terdiri atas tersedianya fasilitas kesehatan, kemudahan untuk menjangkau sarana kesehatan serta keadaan sosial ekonomi dan budaya. Jarak tempat tinggal ke tempat pelayanan kesehatan akan mempengaruhi pasien dalam menyelesaikan pengobatan. Apabila tempat tinggal tidak berada dalam dalam wilayah pelayanan kesehatan akan memperbesar risiko untuk tidak menyelesaikan pengobatan. ${ }^{12}$

Gangguan jiwa dalam berbagai bentuk adalah penyakit yang sering dijumpai pada semua lapisan masyarakat, penyakit ini dapat menenai setiap orang tanpa mengenal umur, ras, agama maupun status ekonomi. Gangguan jiwa pada umumnya dikenal masyarakat sebagai apa yang disebut gila. Walaupun gangguan jiwa tidak langsung menyebabkan kematian tapi menimbulkan penderitaan yang mendalam bagi individu serta beban berat bagi keluarga.

Kebanyakan pasien jiwa yang ada saat ini kurang mendapatkan perhatian dari keluarga, karena dari fenomena yang ada kebanyakan orang-orang menganggap gangguan jiwa dapat menimbulkan penderitaan yang mendalam bagi individu serta beban berat bagi keluarga. Dan gangguan jiwa tersebut terbagi beberapa golongan yakni berat (psikosis), ringan, kepribadian, penyalahgunaan zat dan retradasi mental. Tidak jarang mereka mengurung dan juga memasung apabila ada salah satu keluarga yang mengalami ganguan jiwa. Hal ini dilakukan karena keluarga pasien kurang mengerti perawatan pasien gangguan jiwa dan adanya persepsi yang salah tentang gangguan jiwa.

Dari uraian di atas, kondisi tersebut dapat Diatasi dengan memberikan persepsi tentang ganguaan jiwa bahwa kesehatan jiwa adalah bagian dari tubuh, maka perlu diperiksakan. Jika jiwa sakit sama dengan fisik yang mengalami sakit. Persepsi keluarga yang tepat tentang gangguan jiwa sangat penting dan diperlukan, terutama untuk keteraturan pemeriksaan gangguan jiwa. karena untuk pasien dengan gangguan jiwa diperlukan untuk teratur berobat dan teratur untuk periksa, supaya ganguan jiwa yang dialami bisa ditangani.

Menurut Wiliiam persepsi merupakan suatu pengalaman yang terbentuk berupa data yang didapat melalui indera, hasil pengolahan otak dan ingatan. Persepsi dibagi menjadi 2 
jenis yaitu persepsi positif adalah persepsi yang menggambarkan segala pengetahuan (tahu tidaknya dan kenal tidaknya) dalam tanggapan yang diteruskan kepada pemanfaatannya dan persepsi negatif adalah persepsi yang menggambarkan segala pengetahuan (tahu tidaknya dan kenal tidaknya) serta tanggapan yang tidak selaras dengan objek yang diekspresikan. ${ }^{13}$

Sebagian besar keluarga pasien memiliki persepsi yang positif hal itu bisa dibuktikan dengan sebagian besar keluarga yang mengantar keluarganya yang mengalami gangguan jiwa bisa menerima kondisi keluarganya, selalu memberi kasih sayang dan memnhi kebutuhan sehari-hari bahkan keluarga berupaya untuk mengembalikan kondisi keluarganya yang mengalami gangguan jiwa seperti semula. Dari fenomena ini bisa disimpulkan bahwa persepsi keluarga yang positif sangatlah penting.

Sehingga persepsi keluarga tentang gangguan jiwa sangat penting dan berarti dalam keteraturan pemeriksaan dan pengobatan. Tetapi Selama ini banyak keluarga yang salah persepsi tentang gangguan jiwa, mereka mengira bahwa jika ada salah satu anggota keluarga yang megalami gangguan jiwa itu sangat memalukan dan menganggapnya aib keluarga, sehingga kebanyakan pasien jiwa sering ditelantarkan bahkan sampai dibuang oleh keluarganya sendiri, ada juga persepsi keluarga yang menyebutkan bahwa gangguan jiwa yang dialami pasien adalah akibat kutukan, roh jahat sehingga seringkali keluarga membawa ke dukun. Dari hal tersebut merupakan persepsi keluarga yang salah untuk penanganan gangguan jiwa.

Penderita gangguan jiwa adalah seseorang yang mengalami gangguan atau kekurangan mental yang disebabkan oleh penyakit dan lingkungan, seperti masalah keluarga, sosial, dan trauma masa lalu. Penderita gangguan jiwa disebabkan karena adanya tekanan dari lingkungan keluarga. Di Bali, terdapat sistem dimana dalam satu natah terdapat keluarga besar yang terdiri dari banyak kepala keluarga. Hal tersebut sering memicu konflik seperti perebutan harta warisan yang menyebabkan salah satu pihak merasa tertekan hingga mengalami gangguan mental. Penderita gangguan jiwa yang memiliki masalah keluarga atau trauma fisik cenderung dikucilkan oleh orang sekitar. Pengobatan untuk penderita gangguan jiwa dapat dilakukan dengan membawa penderita gangguan jiwa ke psikiater atau dokter spesialis kejiwaan. Keluarga dapat berkonsultasi mengenai keadaan upaya penanganan terhadap penderita gangguan jiwa.

Ada beberapa kemungkinan yang menyebabkan tingginya tingkat pengangguran bagi mereka yang menderita penyakit jiwa serius. Pertama, kuatnya stigma bahwa penderita penyakit iwa tidak mampu bekeria dan berkarya. Keluarga juga sering memberikan bantuan yang berlebihan yang akhirnya menyebabkan penderita semakin tergantung pada orang lain. Contohnya, penderita sering dibebaskan dari tanggung jawab keseharian seperti memasak, mencuci, atau bekerja.

Tentu ada waktunya ketika memberikan dukungan secara emosional akan berpengaruh positif bagi keluarga yang menderita penyakit jiwa. Namun jika keluarga terlalu sering mengambil-alih tanggung jawab, membiarkan si penderita menghindari banyak hal dalam hidup, akan sulit bagi penderita untuk belajar menghadapi stres dalam kehidupan sehari-hari. Berbagai penelitian menunjukan bahwa memberikan bantuan yang berlebihan (disebut "symptoms accomodation") justru membuat penderita semakin sulit mengatasi penyakit jiwa, seperti masalah depresi dan cemas.

Gangguan jiwa psikosis merupakan istilah medis yang merujuk pada keadaan mental yang terganggu oleh delusi atau halusinasi. Kondisi ini merupakan kondisi ketika pengidap tidak bisa membedakan imajinasi dan kenyataan.

Upaya penyembuhan pada gangguan mental ini dapat ditempuh dengan dua cara, yaitu dengan fisioterapi dan obat-obatan. Biasanya, proses penyembuhan merupakan kombinasi dari kedua cara tersebut. Hal yang paling menentukan untuk kesembuhan kondisi ini adalah keluarga. Keluarga diharuskan untuk mendukung dan memahami jika gangguan mental ini memerlukan waktu yang cukup lama untuk penyembuhannya. Mengapa proses penyembuhan ini memakan waktu yang lama, $\mathrm{Hal}$ ini dikarenakan stigma masyarakat terhadap pengidap psikosis sebagai orang gila dan mengucilkannya. Akibatnya, proses penyembuhan psikosis membutuhkan waktu yang cukup lama. Meskipun proses penyembuhannya cukup lama, gangguan mental psikosis dapat disembuhkan.

Dengan adanya kepercayaan yang positif pasien dapat meminum obat. Obat gangguan jiwa dapat mengurangi gejala yang 
dialami pasien. Obat yang diresepkan oleh dokter bekerja langsung memperbaiki atau menyeimbangkan kadar senyawa kimia dalam otak untuk memperbaiki suasana hati dan mengurangi efek samping fisik yang dapat menyertai gejalanya, seperti badan lemas, insomnia, mual, dan lain sebagainya dengan harapan agar Anda bisa berpikir lebih jernih dan menemukan motivasi untuk bangkit kembali dari keterpurukan.

\section{KESIMPULAN DAN SARAN}

Berdasarkan hasil penelitian, diketahui bahwa adapun faktor yang memengaruhi kejadian putus berobat terhadap pasien gangguan jiwa rawat jalan di Rumah Sakit Jiwa Kalawa Atei Kalimantan Tengah tahun 2019 adalah kemampuan ekonomi $(p=0,024)$, jarak $(p=0,000)$, persepsi $(p=0,012)$, kepercayaan $(p=0,001)$.

Berdasarkan hasil penelitian disarankan agar penelitian ini dapat dijadikan sebagai salah satu sumber informasi terkait dengan faktor yang mempengaruhi kejadian putus berobat terhadap pasien gangguan jiwa di Rumah Sakit Jiwa.

\section{DAFTAR PUSTAKA}

1. Kementerian Kesehatan. Riset Kesehatan Dasar (Riskesdas) "Penderita Gannguan Mental." Kemenkes RI. 2017;

2. Kementerian Kesehatan Republik Indonesia. Kesehatan Jiwa Masyarakat. 2016;

3. Kesehatan Jiwa di Indonesia Masih Terabaikan. 2018

4. Southeast Asia Mental Health Forum 2018

5. Hawari D. Manajemen Stres, Cemas dan Depresi Edisi 2. Cet Pertama Jakarta
Gaya Baru. 2006;

6. Rumah Sakit Jiwa Kalawa Atei Rumah rsjkalawaatei.kalteng.go.id/index

7. Friedman, M. M., Bowden, V. R., \& Jones, E. G. Family nursing textbook: Research, theory, and practice of. Jakarta: EGC; 2010

8. Sariah, A. E., Outwater, A. H., \& Malima, K. I. Risk and protective factors for relapse among individuals with schizophrenia: a qualitative study in Dar es Salaam, Tanzania. BMC psychiatry, 14(1), 240; 2014

9. Iswanti, D. I. Pengaruh Terapi Perilaku Modeling Partisipan Terhadap Kepatuhan Minum Obat Pada Klien Penatalaksanaan Regimen Terapeutik Tidak Efektif di RSJD Dr. Amino Gondohutama Semarang. Universitas Indonesia. Available at: http://lib. ui. ac. id/opac/ui/detail. jsp; 2012

10. Deris Yulia, Defananda. Faktor-Faktor Yang Mempengaruhi Kepatuhan Dalam Menjalankan Program Rawat Jalan Pada Pasien Dengan Gangguan Jiwa Di Dusun Bendorejo Desa Sumberagung Kecamatan Ngantang. 2018. PhD Thesis. University of Muhammadiyah Malang.

11. Keliat, B. A dkk (2011). Manajemen Kasus Gangguan Jiwa: CMHN ( Intermediate Course) EGC: Jakarta

12. Niven, P. R. Balanced scorecard step-bystep: Maximizing performance and maintaining results. John Wiley \& Sons; 2012

13. William. Hubungan antara dukungan keluarga dengan keberfungsian sosial pada pasien skizofrenia pasca perawatan di rimah sakit.Fakultas Psikologi Universitas Diponegoro, tidak dipublikasikan; 